Sains Malaysiana 50(6)(2021): 1707-1714

http://doi.org/10.17576/jsm-2021-5006-17

\title{
Efficacy of Granisetron in the Prevention of Nausea and Vomiting among Paediatric Oncology Patients Receiving Moderate to Highly Emetogenic Chemotherapy: A Single-Blinded, Non-Inferiority Trial
}

(Keberkesanan Granisetron dalam Mencegah Loya dan Muntah di Kalangan Pesakit Pediatrik Onkologi yang Menerima Kimoterapi Emetogenik Sederhana hingga Tinggi: Suatu Kajian Kesamarataan, Rabun Satu Pihak)

\author{
Sie Chong Doris Lau, Cheng Khai Soh, C-KHai Loh, Syed Zulkifli Syed Zakaria \& Hamidah Alias*
}

\section{ABSTRACT}

This single-blinded, non-inferiority trial was conducted over an 8-month period to examine the efficacy of intravenous granisetron at two differing doses in preventing acute and delayed chemotherapy-induced nausea and vomiting (CINV) among paediatric patients receiving moderate to highly emetogenic chemotherapy. Seventeen patients ( 9 males and 8 females) were recruited and randomly assigned to receive alternating granisetron dosages of $0.01 \mathrm{mg} / \mathrm{kg}$ and $0.04 \mathrm{mg} /$ $\mathrm{kg}$ during each chemotherapy cycle. The severity of CINV during and three days post-completion of chemotherapy, as well as common side effects of granisetron were recorded. A total of 78 cycles of chemotherapy (38 cycles of $0.01 \mathrm{mg} / \mathrm{kg}$ and 40 cycles of $0.04 \mathrm{mg} / \mathrm{kg}$ ) were evaluated. The median age of the study population was 5.2 years (interquartile range 25th, 3.8; 75th, 8.7). Patients' diagnoses comprised of haematological malignancy, bone tumour and cerebral neoplasm. From this study, we demonstrated that intravenous (IV) granisetron $0.01 \mathrm{mg} / \mathrm{kg}$ was non-inferior to $0.04 \mathrm{mg} / \mathrm{kg}$ in terms of achieving a complete response for acute CINV. However, a similar observation was not seen in the post-treatment period analysis (delayed CINV). In conclusion, IV granisetron at $0.04 \mathrm{mg} / \mathrm{kg} /$ dose provides effective protection and prophylaxis of both acute and delayed CINV. Further study with a larger sample size may be required before a definite conclusion can be made with regards to efficacy of $0.01 \mathrm{mg} / \mathrm{kg}$ dose.

Keywords: Chemotherapy; granisetron; nausea and vomiting; non-inferiority; paediatric

\section{ABSTRAK}

Kajian kesamarataan, rabun satu pihak ini dijalankan selama tempoh 8 bulan untuk melihat keberkesanan ubat granisetron intravena pada 2 dos yang berbeza dalam mencegah loya dan muntah di kalangan pesakit pediatrik yang menerima kemoterapi tahap emetogenik sederhana hingga tinggi. Tujuh belas pesakit (9 lelaki dan 8 perempuan) telah direkrut dan dibahagikan secara rawak untuk menerima dos granisetron $0.01 \mathrm{mg} / \mathrm{kg}$ dan $0.04 \mathrm{mg} / \mathrm{kg}$ secara berselang setiap kitaran kemoterapi. Tahap keterukan loya dan muntah semasa (akut) dan 3 hari selepas (tertangguh) kemoterapi, serta kesan sampingan granisetron dicatatkan. Sebanyak 78 kitaran kemoterapi (38 kitaran dengan dos $0.01 \mathrm{mg} /$ $\mathrm{kg}$ dan 40 kitaran dengan dos $0.04 \mathrm{mg} / \mathrm{kg}$ ) telah dikaji. Umur median pesakit kajian adalah 5.2 tahun (kuartil ke-25, 3.8; ke-75, 8.7). Diagnosa pesakit merangkumi kanser darah, tulang dan otak. Daripada kajian ini, kami menunjukkan bahawa granisetron intravena dos $0.01 \mathrm{mg} / \mathrm{kg}$ tidak kurang keberkesanannya apabila dibandingkan dengan dos 0.04 $\mathrm{mg} / \mathrm{kg}$ untuk mencapai respons sepenuhnya bagi mencegah loya dan muntah akut. Namun, pemerhatian yang sama tidak dilihat untuk loya dan muntah tertangguh selepas kemoterapi. Kesimpulannya, dos granisetron intravena $0.04 \mathrm{mg} / \mathrm{kg}$ memberikan perlindungan dan pencegahan yang berkesan untuk loya dan muntah akut serta tertangguh. Kajian lanjut dengan saiz sampel yang lebih besar diperlukan sebelum kesimpulan yang pasti boleh dibuat mengenai keberkesanan dos $0.01 \mathrm{mg} / \mathrm{kg}$.

Kata kunci: Kemoterapi; granisetron; kesamarataan; loya dan muntah; pediatrik 


\section{INTRODUCTION}

Nausea and vomiting are common side effects of cytotoxic therapy, which are subjected to widely varying patient and treatment specific factors (Hesketh 2008). Chemotherapyinduced nausea and vomiting (CINV) is now largely preventable with the advent of newer and more effective anti-emetic agents (Dupuis \& Nathan 2010; Flank et al. 2016). CINV may be acute, delayed, or anticipatory (Bender et al. 2002). Acute CINV begins within min of chemotherapy administration and resolves within $24 \mathrm{~h}$ while delayed CINV can persist for several days (Bender et al. 2002). Anticipatory emesis, on the other hand, occurs before chemotherapy is given, once an association has been established between the environment and CINV (Morrow et al. 1998; Roscoe et al. 2011). Chemotherapy emetogenicity is the strongest known predictor of CINV in children, hence the chemotherapy emetogenicity classification system was developed to assist clinicians in their management of CINV in patients with paediatric cancer (Dupuis et al. 2011).

Granisetron is a potent and highly selective 5 hydroxytryptamine-3 receptor blocker (5-HT3 antagonist) which is proven to be safe and effective as prophylaxis of nausea and emesis during administration of moderate to highly emetogenic chemotherapy in patients with paediatric cancer (Aksoylar et al. 2001; Hählen et al. 1995). The recommended intravenous dose of granisetron in paediatrics was $0.04 \mathrm{mg} / \mathrm{kg} /$ dose daily, with the first dose given within one hour of initiation of chemotherapy (Dupuis et al. 2013). Several studies have been done to determine the lowest fully effective dose required by granisetron to provide optimal protection against CINV in the paediatric population. However, these studies were limited and showed varying outcomes with the use of differing doses of granisetron. While some have reported comparable effectiveness between $0.02 \mathrm{mg} / \mathrm{kg}$ and 0.04 $\mathrm{mg} / \mathrm{kg}$ dosing, others have demonstrated conflicting results indicating a superiority of the $0.04 \mathrm{mg} / \mathrm{kg}$ dosing compared to $0.02 \mathrm{mg} / \mathrm{kg}$ in preventing CINV (Baxter et al. 1999; Komada et al. 1991; Lemerle et al. 1991). A study by Berrak et al. (2007) demonstrated that granisetron at $0.01 \mathrm{mg} / \mathrm{kg}$ and $0.04 \mathrm{mg} / \mathrm{kg}$ have comparable efficacy in controlling carboplatin-induced acute and delayed nausea/emesis. In majority of these studies, granisetron was found to be well tolerated with no major adverse events.

We used intravenous (IV) granisetron $0.05 \mathrm{mg} / \mathrm{kg}$ once or twice a day as first line anti-emetic in its IV form for in-patient chemotherapy treatments in our paediatric oncology unit. IV metoclopramide or dexamethasone will be used as second line anti-emetic if the CINV is not controlled with IV granisetron alone. Oral granisetron is occasionally prescribed upon discharge in anticipation of delayed CINV. In this study, we aimed not only to determine the efficacy of IV granisetron $0.04 \mathrm{mg} / \mathrm{kg} / \mathrm{dose}$ in preventing CINV in our patients, but also to compare its efficacy with a lower dose granisetron of $0.01 \mathrm{mg}$ / $\mathrm{kg} /$ dose. We also sought to determine the incidence of adverse effects (headache, constipation, and diarrhoea) of granisetron experienced by our patients.

\section{METHODS}

This was a single-blinded, dose-comparison, noninferiority trial which was carried out in a paediatric oncology ward at a tertiary referral centre over an 8-month period. All patients with paediatric cancer aged 3-18 years, who were receiving moderate to highly emetogenic chemotherapy during the study period were identified from the database. Patients with documented severe CINV during previous chemotherapy cycles were excluded from the study. Parents or guardians of the eligible patients were approached and written informed consent was obtained prior to the recruitment of the patients.

The emetogenicity of chemotherapy drugs were classified based on the Paediatric Oncology Group of Ontario antineoplastic-induced nausea and vomiting guideline. Both high and moderate emetogenicity were defined as a $>90 \%$ and $30-90 \%$ chance of causing emesis when anti-emetic prophylaxis was not provided (Dupuis et al. 2011). The Baxter face retching scale was used to assess the degree of nausea in our study (Baxter et al. 2011). Ethical approval was obtained from the Institutional Research Ethics Committee prior to the study (FF-2014262).

\section{SINGLE-BLIND RANDOMISATION}

One investigator was appointed from the team prior to commencement of the study to perform the randomisation after recruitment. Patients admitted for moderate to highly emetogenic chemotherapy could either have a one-day regime or multi-day regime according to their treatment protocols. Upon admission and enrolment into the study, the parents were given a pouch containing two coloured marbles, one red and one blue. They were asked to randomly pick a marble without looking into the pouch; the colour of the marble chosen was noted by the recruiting investigator. The definition of this colour code was known only to the 
recruiting investigator, who then assigned the patients into two groups of either $0.01 \mathrm{mg} / \mathrm{kg}$ (red marble) or $0.04 \mathrm{mg} / \mathrm{kg}$ (blue marble) dose of IV granisetron. This investigator was also responsible for the preparation of the IV granisetron before passing them to the nurses to be administered.

Both dosages of granisetron were prepared similarly into a $5 \mathrm{~mL}$ volume. The syringes were labelled only with the name of the patients and identifying number; the dosage received by the patients during each cycle were recorded in a separate notebook kept by the investigator; no dosage was written on the syringe label or on the prescription chart of the patients. The nurses were instructed to administer granisetron as a slow IV infusion over $10 \mathrm{~min}$, half an hour before the start of chemotherapy and twice a day (12 hourly) thereafter in multi-day chemotherapy regimens.

During admission, the recruiting investigator met with the patients and parents everyday (for multi-day chemotherapy regime) or prior to discharge (for singleday regime) and during the outpatient review three days' post-discharge and assessed their response. Neither the parents nor the patients were aware of the dose of granisetron given. During the subsequent admissions, patients were given alternate dosages of IV granisetron until the completion of their treatment course or until the end of the study period, whichever came first (Figure 1). Intervals between two consequent chemotherapy cycles were at least one week apart to prevent residual effect from a previous different dose of granisetron.

\section{ASSESSMENT OF RESPONSE}

The degree of nausea was documented at six hourly intervals from the time of initiation of chemotherapy using the Baxter face retching scale; score of 2: minor nausea, 4 or 6 : moderate and 8 or 10: severe nausea (Baxter et al. 2011). The parents/patients were given a self-report diary card to record the most severe CINV response with its timing, along with the episodes of emesis during chemotherapy and the first three days after completion of chemotherapy. Adverse events experienced by the patients were also recorded. The self-report diary cards were reviewed by the recruiting investigator daily while the patients were admitted to confirm the accuracy of the response recorded by the parents/patients. Three days after discharge, the patients were reviewed at the daycare unit and the completed self-report diary cards were collected.

Responses to granisetron were categorised into: complete response, defined as absence of vomiting or minor or no nausea; major response, defined as one vomiting episode per day or moderate nausea; minor response, defined as two to four episodes of vomiting per day independent of nausea; and failure of treatment, defined as more than four vomiting episodes per day. Episodes of vomiting within 5 min of each other were counted as one episode while vomiting episodes which were 5 min or more apart were counted separately. Patients who developed minor response or failure of treatment in either group received additional IV dexamethasone $4 \mathrm{mg} /$ $\mathrm{m}^{2} 6$ hourly to control the emesis.

\section{SAMPLE SIZE}

Based on the previous study by Berrak et al. (2007), 78.5 and $69.2 \%$ of patients who received IV granisetron at dosages of 0.04 and $0.01 \mathrm{mg} / \mathrm{kg}$, respectively, achieved complete response rates. In order to achieve a power of $80 \%$ and significance level of 5\%, a sample size of 107 'chemotherapy cycles' per arm was required.

\section{STATISTICAL ANALYSIS}

Based on the four response groups, patients were further classified into two groups; those who achieved complete response and those who did not achieved complete response during in-patient (acute) and post-treatment (delayed) period. In the same manner, patients who required rescue treatment and those who did not required rescue treatment were also recorded and compared. Data were analysed by comparing the $95 \%$ confidence interval (CI) in relation to the designated delta value of non-inferiority $(\Delta \mathrm{NI})$, i.e. $5 \%$ (half of the demonstrated complete response rate as reported by Berrak et al. (2007)). We only analysed the patient response of the first day in term of complete response and requirement for rescue therapy because of the inhomogeneity of the chemotherapy treatment protocol. The delayed response (post-treatment period) for all patients (both one-day and multi-day regime) were compared and analysed as a group.

\section{RESULTS}

Seventeen children with cancer receiving moderate to highly emetogenic chemotherapy were enrolled into this study (Table 1). Nine out of the 10 patients with acute lymphoblastic leukaemia (ALL) were recruited at the delayed intensification phase (receiving either doxorubicin or cyclophosphamide). One patient had relapsed ALL and was receiving high dose methotrexate and later, cyclophosphamide during the study period. Meanwhile, one patient was diagnosed with T-lymphoblastic 
lymphoma and was randomised while receiving weekly daunorubicin during induction phase chemotherapy.

Granisetron anti-emetic efficacy and adverse effects were evaluated during 78 chemotherapy cycles; 0.01 $\mathrm{mg} / \mathrm{kg}$ was used in 38 chemotherapy cycles while 0.04 $\mathrm{mg} / \mathrm{kg}$ was used in 40 chemotherapy cycles. Treatment characteristics of the study group are demonstrated in Table 2. A majority of the patients achieved complete response in both dosage groups while receiving day 1 chemotherapy ( $86 \%$ in the $0.01 \mathrm{mg} / \mathrm{kg}$ group versus $98 \%$ in the 0.04 $\mathrm{mg} / \mathrm{kg}$ group) (Table 3 ). This reflects the effectiveness of both dosage groups in controlling acute CINV in our study populations. However, only $79 \%$ of patients in the 0.01 $\mathrm{mg} / \mathrm{kg}$ groups reported complete response during the first 3 days post chemotherapy compared to $92 \%$ of patients in the $0.04 \mathrm{mg} / \mathrm{kg}$ group. Dexamethasone was given as rescue treatment for 3 out of the 38 chemotherapy cycles with the $0.01 \mathrm{mg} / \mathrm{kg}$ group, while none of the patients in the $0.04 \mathrm{mg} / \mathrm{kg}$ group required any rescue treatment.

The $\Delta \mathrm{NI}$ in this study was -0.05 ; the region of noninferiority was -0.05 and above. Our result of $95 \%$ CI was more than the $\Delta \mathrm{NI}$, indicating that IV granisetron $0.01 \mathrm{mg} /$ $\mathrm{kg}$ was non-inferior compared to $0.04 \mathrm{mg} / \mathrm{kg}$ in term of achieving complete response (acute CINV) in our patients (Figure 2(a)). Similarly, in terms of rescue treatment required, we were able to demonstrate the NI of $0.01 \mathrm{mg} / \mathrm{kg}$ of IV granisetron compared to $0.04 \mathrm{mg} / \mathrm{kg}$ on the first day of treatment (Figure 2(b)). However, we failed to show the non-inferiority of $0.01 \mathrm{mg} / \mathrm{kg}$ of IV granisetron compared to $0.04 \mathrm{mg} / \mathrm{kg}$ for protection against delayed CINV as the 95\% CI was less than the $\Delta \mathrm{NI}$ (Figure 2(c)).

Constipation (three patients) was the most common adverse effect associated with granisetron observed in our study, although these patients were also receiving vincristine during the study period. None of the patients withdrew from the trial because of adverse effects from granisetron.

When we analysed the emetogenicity of the drugs received by both groups, patients with leukaemia/ lymphoma received less emetogenic chemotherapy compared to patients with brain/bone tumours $(p<0.001)$. In our study, the granisetron dose of $0.04 \mathrm{mg} / \mathrm{kg}$ offered equal protection for patients in both the leukaemia/ lymphoma group and brain/bone tumour group on the first day and 3 days post chemotherapy ( $p=0.307$ and $p=$ 0.813 , respectively). However, for granisetron at the dose of $0.01 \mathrm{mg} / \mathrm{kg}$, the Baxter score of patients was slightly higher for patients with brain/bone tumours compared to those with leukaemia/lymphoma on the first day of chemotherapy (mean score 1.755 (Standard deviation (SD) $\pm 0.971)$ vs $1.130(\mathrm{SD} \pm 0.625) ; p=0.038)$. There was no statistically significant difference in the Baxter score recorded 3 days post-treatment between both groups ( $p=$ 0.092) for the lower granisetron dosage.

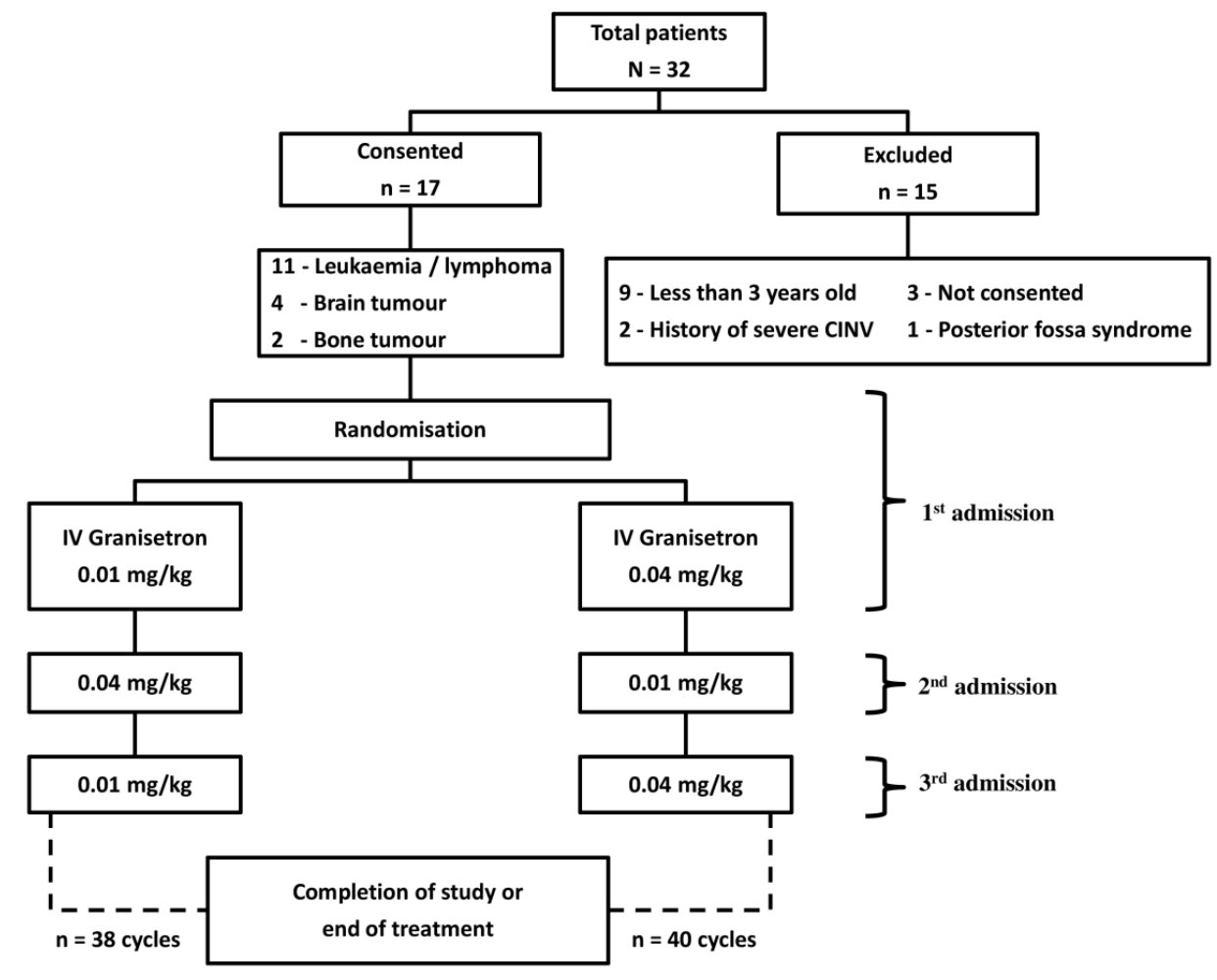

FIGURE 1. Flow chart of patient recruitment and randomisation 


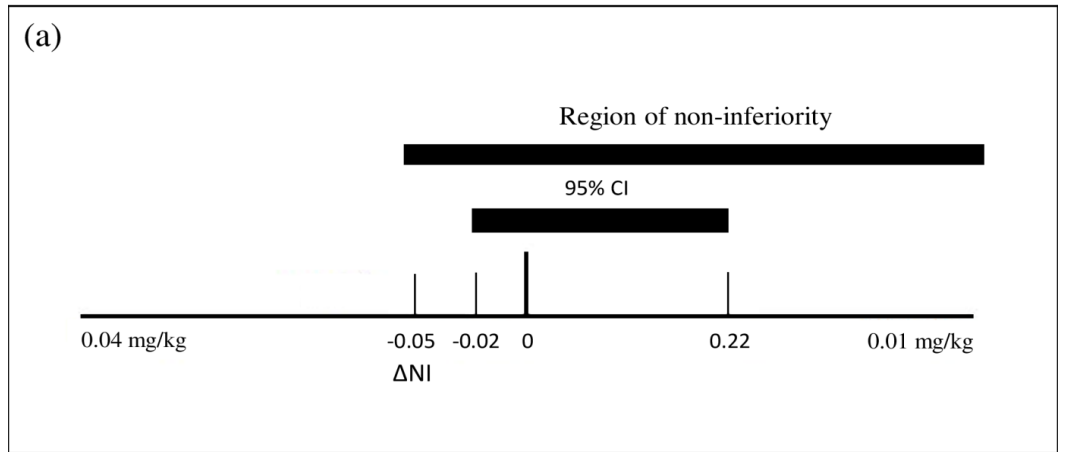

(b)
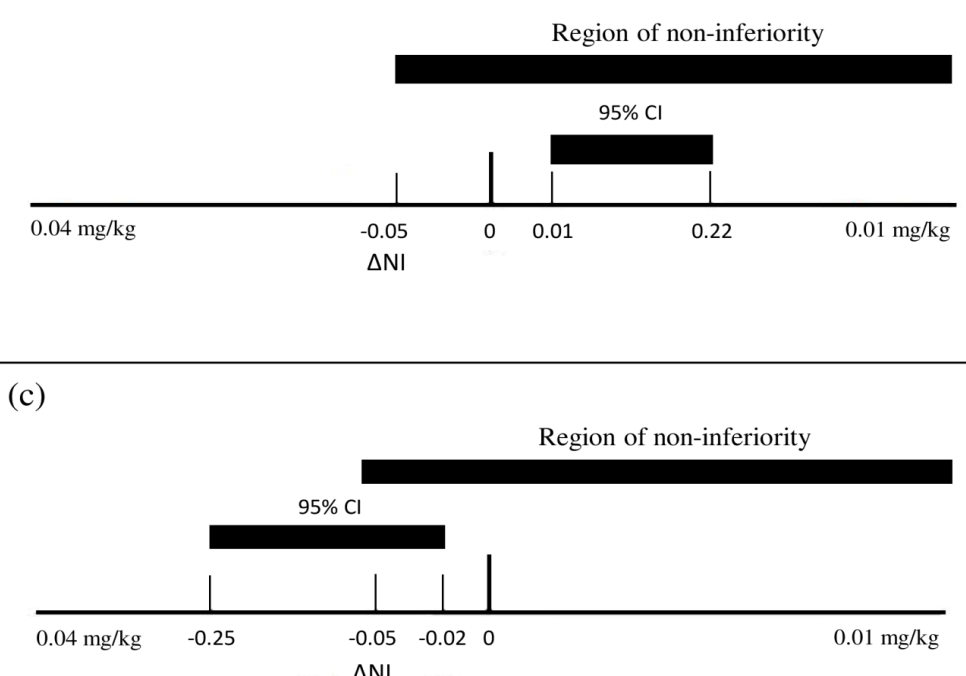

FIGURE 2. Region of non-inferiority for (a) complete response rate on first day chemotherapy, (b) Day 1 dexamethasone rescue rate, and (c) post-treatment complete response rate between both dosage groups

CI, confidence interval; NI, non-inferiority

TABLE 1. Demographic characteristics of study populations

\begin{tabular}{lc}
\hline Characteristic & $\begin{array}{c}\text { Results } \\
(\mathrm{N}=17)\end{array}$ \\
\hline Age at study entry in years, median (IQR) & $5.25(3.88-8.70)$ \\
Gender, n (\%) & $9(53)$ \\
Male & $8(47)$ \\
Female & $4.83(3.46-8.00)$ \\
Age at diagnosis in years, median (IQR) & $4.76(1.31-6.81)$ \\
Duration of prior chemotherapy exposure in months, median (IQR) & $13(76)$ \\
Ethnicity, n (\%) & $2(12)$ \\
Malay & $2(12)$ \\
Chinese & \\
Indian & $11(65)$ \\
Diagnosis, $n(\%)$ & $4(23)$ \\
Acute leukaemia/lymphoma & $2(12)$ \\
\hline
\end{tabular}

$\mathrm{N}$, number; IQR, Interquartile range 
TABLE 2. Treatment characteristics of the study groups

\begin{tabular}{lcc}
\hline Treatment variables & IV Granisetron $(\mathrm{N}=78)$ & $0.04 \mathrm{mg} / \mathrm{kg}$ \\
\hline All episodes, $\mathrm{n}(\%)$ & $38(48.7)$ & $40(51.3)$ \\
Chemotherapy regime, day & 30 & 33 \\
1 day, $\mathrm{n}=63$ & 4 & 3 \\
2 days, $\mathrm{n}=7$ & 4 & 4 \\
$\geq 3$ days, $\mathrm{n}=8$ & & 15 \\
Chemotherapy emetogenicity, $p=0.989 *$ & 14 & 25 \\
High level & 24 & \\
Moderate level & & \\
\hline n, number & & \\
*statistical analysis using Chi-square test (significant $p$ value $<0.05)$ & & \\
\end{tabular}

TABLE 3. Response rate based on dosage groups

\begin{tabular}{|c|c|c|c|c|}
\hline \multirow[t]{2}{*}{ Groups } & \multicolumn{2}{|c|}{ Day 1 chemotherapy, n (\%) } & \multicolumn{2}{|c|}{ Three days post-chemotherapy, n (\%) } \\
\hline & Complete response & $\begin{array}{l}\text { Incomplete } \\
\text { response }\end{array}$ & $\begin{array}{l}\text { Complete } \\
\text { response }\end{array}$ & Incomplete response \\
\hline Overall & 72 & 6 & 67 & 11 \\
\hline $0.01 \mathrm{mg} / \mathrm{kg}$ & $33(86)$ & $5(13)$ & $30(79)$ & $8(21)$ \\
\hline $0.04 \mathrm{mg} / \mathrm{kg}$ & $39(98)$ & $1(2)$ & $37(92)$ & $3(8)$ \\
\hline \multicolumn{5}{|l|}{ Gender } \\
\hline \multicolumn{5}{|l|}{ Male } \\
\hline $0.01 \mathrm{mg} / \mathrm{kg}$ & $19(90)$ & $2(10)$ & $17(81)$ & $4(19)$ \\
\hline $0.04 \mathrm{mg} / \mathrm{kg}$ & $19(95)$ & $1(5)$ & $18(90)$ & $2(10)$ \\
\hline \multicolumn{5}{|l|}{ Female } \\
\hline $0.01 \mathrm{mg} / \mathrm{kg}$ & $14(82)$ & $3(18)$ & $13(76)$ & $4(23)$ \\
\hline $0.04 \mathrm{mg} / \mathrm{kg}$ & $20(100)$ & $0(0)$ & $19(95)$ & $1(5)$ \\
\hline \multicolumn{5}{|l|}{ Age group } \\
\hline \multicolumn{5}{|l|}{$>7$ years old } \\
\hline $0.01 \mathrm{mg} / \mathrm{kg}$ & $8(67)$ & $4(33)$ & $8(67)$ & $4(33)$ \\
\hline $0.04 \mathrm{mg} / \mathrm{kg}$ & $13(100)$ & $0(0)$ & $12(92)$ & $1(8)$ \\
\hline \multicolumn{5}{|l|}{$\leq 7$ years old } \\
\hline $0.01 \mathrm{mg} / \mathrm{kg}$ & $25(96)$ & $1(4)$ & $22(85)$ & $4(15)$ \\
\hline $0.04 \mathrm{mg} / \mathrm{kg}$ & $26(96)$ & $1(4)$ & $25(93)$ & $2(7)$ \\
\hline
\end{tabular}

n, number 


\section{DISCUSSION}

Granisetron has been reported to be safe and effective as prophylaxis for CINV during the administration of moderate to highly emetogenic chemotherapy in paediatric patients (Berrak et al. 2007; Komada et al. 1991; Lemerle et al. 1991; Tsuchida et al. 1999). In our study, we successfully proved that IV granisetron of $0.01 \mathrm{mg} / \mathrm{kg}$ was non-inferior to $0.04 \mathrm{mg} / \mathrm{kg}$ in preventing acute CINV during administration of highly emetogenic chemotherapy. This finding corroborates a previous study done by Berrak et al. (2007). However, we failed to demonstrate the NI of $0.01 \mathrm{mg} / \mathrm{kg}$ compared to $0.04 \mathrm{mg} / \mathrm{kg}$ for protection against delayed CINV.

The Multinational Association of Supportive Care in Cancer paediatric guideline for prevention of acute CINV in 2016 recommends the use of 5-HT3 antagonist (granisetron, ondansetron, palonosetron or topisetron) with dexamethasone and aprepitant as anti-emetic prophylaxis for children receiving highly emetogenic chemotherapy (Dupuis et al. 2017). Those receiving moderately emetogenic chemotherapy should receive a 5-HT3 antagonist with dexamethasone (Dupuis et al. 2017). Randomised studies included in the systematic reviews for the guideline reported the granisetron doses of $0.02 \mathrm{mg} / \mathrm{kg}$ and $0.04 \mathrm{mg} / \mathrm{kg}$ as efficacious in preventing acute CINV, although the recommendation for the optimal dose of granisetron was not included in this guideline (Aksoylar et al. 2001; Emir et al. 2013; Hählen et al. 1995; Jaing et al. 2004; Mabro et al. 2000). However, due to lack of studies, no formal recommendation was made for delayed CINV in children following moderate to highly emetogenic chemotherapy (Dupuis et al. 2017).

In contrast to this guideline which recommends the combination of 5-HT3 antagonist and dexamethasone in children receiving moderately emetogenic chemotherapy, with the addition of aprepitant for those receiving highly emetogenic chemotherapy, our study found that monotherapy with IV granisetron either at 0.04 or 0.01 $\mathrm{mg} / \mathrm{kg}$ twice a day was effective in controlling acute CINV. The use of dexamethasone was not routinely required in our cohort of patients despite the high emetogenicity of the chemotherapy.

The question of optimal anti-emetic dosing for the prevention of delayed CINV in children remains unanswered, hence the varying dosage and regime of anti-emetics used in different centres around the world. Choices of anti-emetics were usually made based on the personal experience of the clinician and availability of the anti-emetic agents at the treating centre. In our study, although granisetron at $0.04 \mathrm{mg} / \mathrm{kg}$ provided adequate protection for delayed CINV in $92 \%$ of the chemotherapy cycles examined, a small proportion of the patients required additional anti-emetic coverage after discharge.

The major limitations of this study were the small sample size and inhomogeneity of diagnosis and treatment protocols in the study cohort. Due to the small number of patients treated at our centre, all patients receiving moderate to highly emetogenic chemotherapy were recruited. In order to minimise the possible bias caused by the different chemotherapy protocols used, we only analysed the response of the first day provided by granisetron. In the setting of strict laws and ethical guidelines limiting drug trials among paediatric population, we feel that our data can contribute to the existing international guidelines on optimal dosage of anti-emetics used in patients of paediatric oncology despite our small sample size. Of course, future large, multi-centre studies would better consolidate our findings, especially with regards to the efficacy of granisetron $0.01 \mathrm{mg} / \mathrm{kg}$ dose.

\section{CONCLUSION}

From our observation, IV granisetron at $0.04 \mathrm{mg} / \mathrm{kg}$ provides effective protection from acute and delayed CINV during administration of moderate to highly emetogenic chemotherapy in our patients of paediatric oncology. Further large, multi-centre studies are required before a definite conclusion can be made with regards to the efficacy of the $0.01 \mathrm{mg} / \mathrm{kg}$ dose.

\section{ETHICS APPROVAL AND CONSENT TO PARTICIPATE}

Ethics approval was obtained from UKM Research Ethics Committee, Universiti Kebangsaan Malaysia in accordance with the ethical standards as laid down in the 1964 Declaration of Helsinki and its later amendments or comparable ethical standards. The Ethic Committee/IRB reference number was FF-2014-262. Informed consent to participate was obtained from each eligible parent prior to recruitment. The authors declared no conflict of interests.

\section{ACKNOWLEDGEMENTS}

This research was approved by Universiti Kebangsaan Malaysia (FF-2014-262, no funding provided). There was also no external funding received from any other organisation. The author's contribution is as follows: Conception and design: HA, CKL. Study coordination: HA, CKS, SC. Randomisation of subjects: CKS. Clinical data collection: CKS, SC. Analysis of data: CKS, SZ. Interpretation of data: HA, CKS, SZ, SC. Drafting and writing 
of manuscript: HA, CKS, SC. Revision of manuscript: HA, CKS, SC, CKL. All authors read and approved the final manuscript. The authors have full control of the primary data collected during the study. We agreed to allow the journal to review the data if requested.

\section{REFERENCES}

Aksoylar, S., Akman, S.A., Özgenç, F. \& Kansoy, S. 2001. Comparison of tropisetron and granisetron in the control of nausea and vomiting in children receiving combined cancer chemotherapy. Pediatric Hematology and Oncology 18(6): 397-406.

Baxter, A.L., Watcha, M.F., Baxter, W.V., Leong, T. \& Wyatt, M.M. 2011. Development and validation of a pictorial nausea rating scale for children. Pediatrics 127(6): e1542-e1549.

Bender, C.M., McDaniel, R.W., Murphy-Ende, K., Pickett, M., Rittenberg, C.N., Rogers, M.P., Schneider, S.M. \& Schwartz, R.N. 2002. Chemotherapy-induced nausea and vomiting. Clinical Journal of Oncology Nursing 6(2): 94-102.

Berrak, S.G., Ozdemir, N., Bakirci, N., Turkkan, E., Canpolat, C., Beker, B. \& Yoruk, A. 2007. A double-blind, crossover, randomized dose-comparison trial of granisetron for the prevention of acute and delayed nausea and emesis in children receiving moderately emetogenic carboplatinbased chemotherapy. Supportive Care in Cancer 15(10): 1163-1168.

Dupuis, L.L. \& Nathan, P.C. 2010. Optimizing emetic control in children receiving antineoplastic therapy beyond the guidelines. Pediatric Drugs 12(1): 51-61.

Dupuis, L.L., Sung, L., Molassiotis, A., Orsey, A.D., Tissing, W. \& van de Wetering, M. 2017. 2016 updated MASCC/ ESMO consensus recommendations: Prevention of acute chemotherapy-induced nausea and vomiting in children. Supportive Care in Cancer 25(1): 323-331.

Dupuis, L.L., Boodhan, S., Holdsworth, M., Robinson, P.D., Hain, R., Portwine, C., O’Shaughnessy, E. \& Sung, L. 2013. Guideline for the prevention of acute nausea and vomiting due to antineoplastic medication in pediatric cancer patients. Pediatric Blood \& Cancer 60(7): 1073-1082.

Dupuis, L.L., Boodhan, S., Sung, L., Portwine, C., Hain, R., McCarthy, P. \& Holdsworth, M. 2011. Guideline for classification of the acute emetogenic potential of antineoplastic medication in pediatric cancer patients. Pediatric Blood \& Cancer 57(2): 191-198.

Emir, S., Erturgut, P. \& Vidinlisan, S. 2013. Comparison of granisetron plus dexamethasone versus an antiemetic cocktail containing midazolam and diphenhydramine for chemotherapy induced nausea and vomiting in children. Indian Journal of Medical and Paediatric Oncology 34(4): 270-273.

Flank, J., Robinson, P.D., Holdsworth, M., Phillips, R., Portwine, C., Gibson, P., Maan, C., Stefin, N., Sung, L. \& Dupuis, L.L. 2016. Guideline for the treatment of breakthrough and the prevention of refractory chemotherapy-induced nausea and vomiting in children with cancer. Pediatric Blood \& Cancer 63(7): 1144-1151.
Hählen, K., Quintana, E., Pinkerton, C.R. \& Cedar, E. 1995. A randomized comparison of intravenously administered granisetron versus chlorpromazine plus dexamethasone in the prevention of ifosfamide-induced emesis in children. The Journal of Pediatrics 126(2): 309-313.

Hesketh, P.J. 2008. Chemotherapy-induced nausea and vomiting. New England Journal of Medicine 358(23): 2482-2494.

Jaing, T.H., Tsay, P.K., Hung, I.J., Yang, C.P. \& Hu, W.Y. 2004. Single-dose oral granisetron versus multidose intravenous ondansetron for moderately emetogenic cyclophosphamidebased chemotherapy in pediatric outpatients with acute lymphoblastic leukemia. Pediatric Hematology and Oncology 21(3): 227-235.

Komada, Y., Matsuyama, T., Takao, A., Hongo, T., Nishimura, Y., Horibe, K. \& Sakurai, M. 1991. A randomised dosecomparison trial of granisetron in preventing emesis in children with leukaemia receiving emetogenic chemotherapy. European Journal of Cancer 35(7): 10951101.

Lemerle, J., Amaral, D., Southall, D.P., Upward, J. \& Murdoch, R.D. 1991. Efficacy and safety of granisetron in the prevention of chemotherapy-induced emesis in paediatric patients. European Journal of Cancer and Clinical Oncology 27(9): 1081-1083.

Mabro, M., Cohn, R., Zanesco, L., Madon, E., Hählen, K., Margueritte, G., Breatnach, F., Gentet, J.C. \& Plouvier, É. 2000. Granisétron en solution buvable dans la prevention des vomissements chimio-induits de l'enfant: Comparison en double aveugle de deux posologies. Bulletin $d u$ Cancer 87(3): 259-264.

Morrow, G.R., Roscoe, J.A., Kirshner, J.J., Hynes, H.E. \& Rosenbluth, R.J. 1998. Anticipatory nausea and vomiting in the era of 5-HT 3 antiemetics. Supportive Care in Cancer 6(3): 244-247.

Roscoe, J.A., Morrow, G.R., Aapro, M.S., Molassiotis, A. \& Olver, I. 2011. Anticipatory nausea and vomiting. Supportive Care in Cancer 19(10): 1533-1538.

Tsuchida, Y., Hayashi, Y., Asami, K., Yamamoto, K., Yokoyama, J., Mugishima, H., Honna, T., Mimaya, J., Hara, F., Sawada, T., Matsumura, T., Suita, S., Sugimoto, T. \& Kaneko, M. 1999. Effects of granisetron in children undergoing highdose chemotherapy: A multi-institutional, cross-over study. International Journal of Oncology 14(4): 673-679.

Department of Paediatrics, Faculty of Medicine Universiti Kebangsaan Malaysia Medical Centre Jalan Yaacob Latif 56000 Kuala Lumpur, Federal Territory Malaysia

*Corresponding author; email: midalias@ppukm.ukm.edu.my

Received: 18 March 2020

Accepted: 15 October 2020 